\title{
OPTIMALISASI PENGGUNAAN AIR PADA PROSES PEMBUATAN SEMI-REFINED CARRAGEENAN (SRC)
}

\author{
Bakti Berlyanto Sedayu*), Jamal Basmal*), dan Bagus Sediadi Bandol Utomo*)
}

\begin{abstract}
ABSTRAK
Penelitian ini bertujuan untuk mengetahui pengaruh pengurangan air pencucian rumput laut pada pembuatan SRC terhadap kualitas produk yang dihasilkan. Pencucian rumput laut dilakukan setelah proses perebusan dengan $\mathrm{KOH}$, yaitu dengan perlakuan tanpa pencucian dan dengan pencucian masing-masing sebanyak 1 , 2, dan 3 kali diikuti dengan pengepresan, dibandingkan kontrol dengan 4 kali pencucian tanpa pengepresan. Perbandingan rumput laut kering dengan air adalah 1:15 (w/v) untuk setiap pencucian. Rumput laut hasil perlakuan dan kontrol kemudian dikeringkan di bawah sinar matahari menjadi SRC. SRC disimpan selama 14 hari pada suhu ruang dan diamati mutunya. Hasil pengamatan menunjukkan bahwa pH SRC berkisar antara 99,5 , gel strength $783-828 \mathrm{~g} / \mathrm{cm}^{2}$, kadar abu tak larut asam 0,02-0,10\%, kadar sulfat 15,37$15,50 \%$, dan viskositas 48,75-74,37 cPs. Dari percobaan yang dilakukan dapat disimpulkan bahwa SRC hasil dari proses pencucian dua kali yang diikuti pengepresan memiliki kualitas baik ditinjau dari aspek kadar abu dan abu tak larut asam yang lebih rendah dibandingkan kontrol, serta kadar air, kadar sulfat, dan kekuatan gel produk yang sama dengan yang diolah dengan pencucian empat kali tanpa pengepresan, meskipun kekentalan dan derajat putihnya sedikit lebih rendah. Dapat disimpulkan bahwa perlakuan pengepresan efektif dalam mengurangi penggunaan air pada proses pengolahan SRC melalui pengurangan jumlah pencucian.

ABSTRACT: Optimalization of water utilization in Semi-Refined Carrageenan (SRC) processing. By: Bakti Berlyanto Sedayu, Jamal Basmal and Bagus Sediadi Bandol Utomo

This experiment was conducted to determine the effect of water reduction during washing of seaweed, on the quality of SRC. After boiling with $\mathrm{KOH}$ solution, the seaweed was subsequently treated by unwashing and washing 1, 2, 3 times followed by pressing, and compared to control which was washed 4 times without pressing. The ratio of dry seaweed and water was 1:15 (w/v) for each washing. The seaweed was then sun dried. The SRC was stored at ambient temperature for 14 days followed by quality assessment. Results of the analysis showed that $\mathrm{pH}$ values of the SRC were between 9-9.5, gel strengths were $783-828 \mathrm{~g} / \mathrm{cm}^{2}$, the contents of acid-insoluble ash were $0.02-0.10 \%$, sulfate contents were $15.37-15.50 \%$, and viscosities were $48.75-74.37$ cPs. Based on results of the experiment, it can be concluded that SRC processed by two times washing followed by pressing has good qualities in terms of ash and acid-insoluble ash content, which were lower than control, whereas water content, sulfate content, and gel strength were indifferent to control. However, the viscosity and the whiteness were slightly lower compared to control. It can be concluded that pressing treatment could effectively reduce the water utilization in SRC processing through reduction of washing times.
\end{abstract}

KEYWORDS: Semi-Refined Carrageenan (SRC), washing times, pressing

\section{PENDAHULUAN}

Hingga saat ini komoditas ekspor hasil pengolahan rumput laut Eucheuma cottonii dari Indonesia umumnya berupa semi-refined carrageenan (SRC) baik dalam bentuk chips atau bubuk. SRC ini dijadikan bahan dasar untuk pembuatan karaginan murni atau diproses lebih lanjut untuk digunakan sebagai bahan pengikat dan penstabil dalam industri makanan ternak untuk pasaran Eropa, Amerika, dan Asia Pasifik. Karaginan adalah polisakarida hasil ekstraksi dari rumput laut merah dengan menggunakan air panas (hot water) atau larutan alkali pada temperatur tinggi (Glicksman 1983). Menurut Hellebust \& Cragie (1978), karaginan terdapat dalam dinding sel rumput laut atau matriks intraselulernya dan merupakan bagian penyusun yang besar dari berat kering rumput laut dibandingkan dengan komponen yang lain.

Kualitas polisakarida dari rumput laut sangat bergantung pada parameter ekstraksi seperti suhu, konsentrasi bahan kimia, rasio rumput laut dengan media pengekstrak, waktu ekstraksi, dan teknik

\footnotetext{
") Peneliti pada Balai Besar Riset Pengolahan Produk dan Bioteknologi Kelautan dan Perikanan, DKP
} 
pemisahan polisakarida rumput laut dari bahan lain seperti selulosa dan garam-garam lainnya. Semua parameter tersebut akan berpengaruh terhadap nilai kekentalan, daya larut, stabilitas, dan kekuatan gel, serta nilai kekakuan produk (Towle, 1973).

Parameter mutu karaginan di pasaran internasional meliputi kadar sulfat, abu, abu tak larut asam, logam berat, dan beberapa parameter lainnya. Standar mutu karagenan di pasaran internasional dapat dilihat pada Tabel 1. proses produksi karaginan (cP Kelco ApS, 2004). Semi-refined carrageenan yang umum dipasarkan secara komersial memiliki pH antara 8-11.

Penggunaan air oleh industri untuk mencuci dan menurunkan $\mathrm{pH}$ rumput laut dalam proses pengolahan SRC sangat besar. Berdasarkan hasil penelitian didapatkan penggunaan air untuk menurunkan $\mathrm{pH}$ rumput laut setelah ekstraksi jumlahnya lebih dari rasio 1:40 (w/v) antara bahan baku dengan air. Pada prakteknya, hal ini kerap menjadi masalah bagi industri

Tabel 1. Standar mutu karagenan

Table 1. Quality standard of carrageenan

\begin{tabular}{lccc}
\hline \multicolumn{1}{c}{ Spesifikasi/Specification } & FAO & FCC & EEC \\
\hline Zat volatil/Volatile compunds (\%) & $\leq 12$ & $\leq 12$ & $\leq 12$ \\
Kadar sulfat/Sulfate content (\%) & $15-40$ & $18-40$ & $15-40$ \\
Kadar abu/Ash content (\%) & $15-40$ & $\leq 35$ & $15-40$ \\
Kekentalan/Viscosity (cPs) & $\geq 5$ & - & - \\
Kadar abu tak larut asam/Acid-insoluble ash content $(\%)$ & $\leq 1$ & $\leq 1$ & $\leq 1$ \\
Kadar logam berat/Heavy metals content: & & & \\
Pb (ppm) & $\leq 10$ & $\leq 10$ & $\leq 10$ \\
As (ppm) & $\leq 3$ & $\leq 3$ & $\leq 3$ \\
Cu (ppm) & - & - & $\leq 50$ \\
Zn (ppm) & - & - & $\leq 25$ \\
\hline
\end{tabular}

Sumber/Source: cP Kelco ApS (2004)

Dalam pembuatan SRC, rumput laut direndam dalam larutan $\mathrm{KOH}$ panas selama beberapa jam. Pengotor seperti protein, lemak, garam-garam laut, dan pigmen warna terekstraksi oleh larutan alkali. Perlakuan dengan larutan alkali juga ditujukan untuk mengubah gugus 6 -sulfat pada unit beta 1,4 galaktosa pada struktur karaginan menjadi 3,6-anhidrogalaktosa yang berperan meningkatkan sifat fungsionalnya seperti kekuatan gel (Bixler \& Johndro, 2000).

Perebusan menggunakan larutan alkali kuat pada proses ekstraksi menghasilkan rumput laut dengan $\mathrm{pH}$ antara 12-14. Untuk menghilangkan residu $\mathrm{KOH}$ berlebih dan menurunkan nilai pH dilakukan pencucian rumput laut menggunakan air bersih. Pada proses pembuatan SRC komersial, pencucian rumput laut setelah perebusan alkali dilakukan dengan jumlah penggunaan air yang tidak baku, lebih tergantung kepada volume bak pencucian yang dimiliki oleh masing-masing perusahaan, dan air untuk mencuci umumnya berkisar 20-40 kali dari bahan baku rumput laut yang digunakan. Hingga kini penelitian mengenai pengaruh pencucian terhadap mutu SRC juga belum pernah dilakukan. Berdasarkan penelitian sebelumnya dilakukan pencucian sebanyak 4 kali untuk menurunkan $\mathrm{pH}$ hingga kisaran 9-10. Berdasarkan sifat kimianya karaginan dalam larutan memiliki stabilitas maksimum pada $\mathrm{pH} 9$ dan akan terhidrolisis pada $\mathrm{pH}$ di bawah 3,5. Pada $\mathrm{pH} 6$ atau lebih umumnya larutan karaginan dapat mempertahankan kondisi pengolahan SRC yang umumnya berada di daerah pesisir di mana ketersediaan air bersih terbatas.

Guna mengefisienkan pemakaian air selama proses pencucian setelah ekstraksi maka pada penelitian ini dilakukan pengurangan jumlah pencucian yang dikombinasikan dengan pengepresan rumput laut untuk memudahkan penghilangan residu $\mathrm{KOH}$ secara mekanis.

\section{BAHAN DAN METODE}

Rumput laut kering jenis Eucheuma cottonii yang berasal dari Madura dibersihkan dengan cara direndam dalam larutan $\mathrm{KOH} 3 \%$ dingin selama 30 menit untuk menghilangkan garam-garam dan kotoran-kotoran dari rumput laut. Kemudian rumput laut direbus dalam larutan $\mathrm{KOH} 8 \%$ dengan perbandingan rumput laut kering dan larutan 1:8 (w/v) pada suhu $75^{\circ} \mathrm{C} \pm 2^{\circ} \mathrm{C}$ selama 3 jam. Selanjutnya rumput laut yang telah direbus dibagi menjadi lima kelompok, kelompok pertama, kedua, dan ketiga dicuci dengan air dengan pencucian sebanyak masingmasing 1,2, dan 3 kali dengan perbandingan rumput laut kering dan air 1:15 untuk sekali pencucian. Setelah dicuci, sebanyak masing-masing $10 \mathrm{~kg}$ rumput laut dipres menggunakan alat pengepres hidrolik dengan tekanan $5,5 \mathrm{~kg} / \mathrm{cm}^{2}$ untuk mengurangi dan menghilangkan air dan larutan $\mathrm{KOH}$ dari rumput laut. Setelah itu rumput laut dikeringkan di bawah sinar 
matahari. Kelompok keempat tidak dicuci langsung dipres dan dikeringkan di bawah sinar matahari, sedangkan kelompok kelima sebagai kontrol, rumput laut hasil perebusan $\mathrm{KOH}$ dicuci sebanyak empat kali (hingga $\mathrm{pH}$ berkisar 9-10) dengan rasio jumlah air yang sama dengan perlakuan lain kemudian langsung dikeringkan menjadi SRC tanpa pengepresan. Percobaan ini dilakukan dengan dua kali ulangan (Gambar 1).

SRC kemudian dianalisis kualitasnya meliputi: $\mathrm{pH}$, kadar air, abu, abu tak larut asam (Horwitz, 1980), sulfat (FAO, 1986), nilai viskositas yang diukur dari larutan SRC $1,5 \%(\mathrm{~b} / \mathrm{v})$ pada suhu $75^{\circ} \mathrm{C}$ dengan menggunakan viscometer (Brookfields), kekuatan gel menggunakan prosedur Marine Colloid (1978), dan derajat putih menggunakan alat whiteness meter.

\section{HASIL DAN BAHASAN}

\section{Keasaman (pH)}

Berdasarkan hasil pengamatan terhadap $\mathrm{pH}$ air selama proses pencucian, terlihat bahwa $\mathrm{pH}$ terus menurun dengan semakin seringnya pencucian. Penurunan $\mathrm{pH}$ air pencucian dapat dilihat pada Gambar 2.

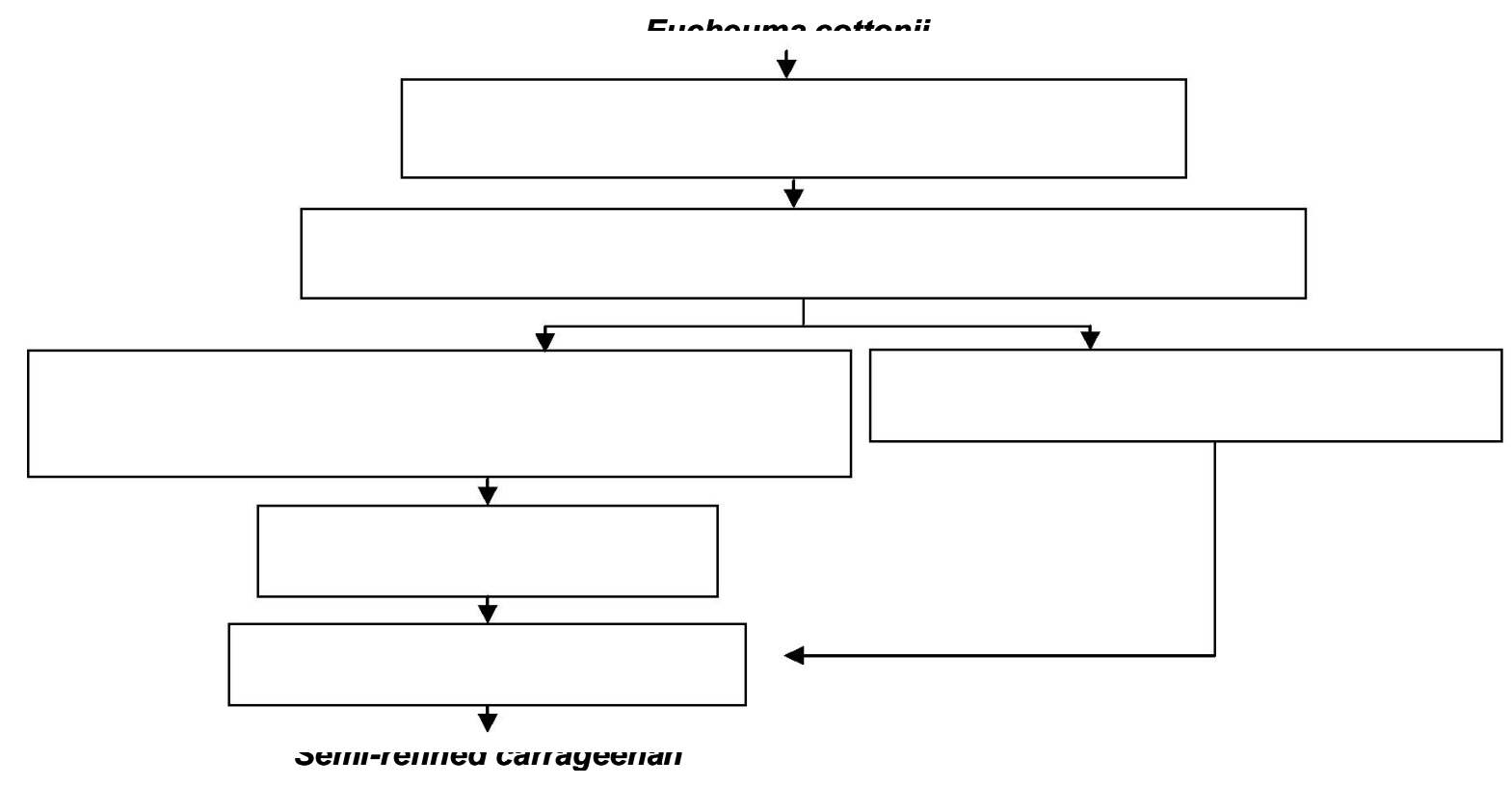

Gambar 1. Alur proses pengolahan SRC.

Figure 1. Flowchart of SRC processing.

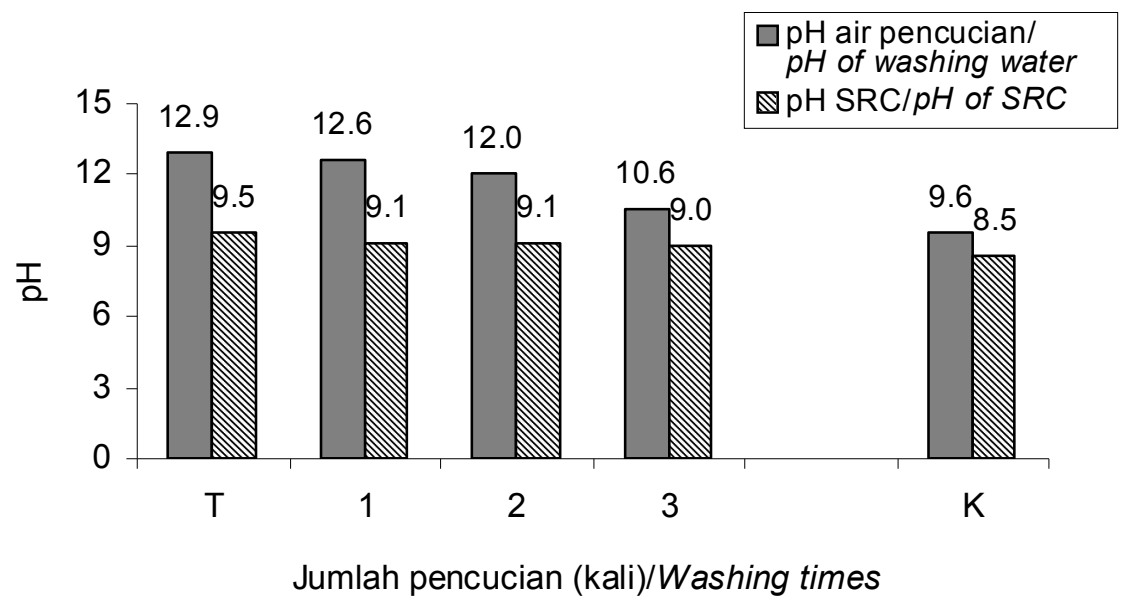

Keterangan/Note: $\mathrm{T}=$ Tidak dicuci/unwashed

$\mathrm{K}=$ kontrol 4 kali pencucian /control 4 washing times

Gambar 2. Pengaruh jumlah pencucian terhadap $\mathrm{pH}$ air pencucian dan SRC yang dihasilkan

Figure 2. Effect of washing times on $\mathrm{pH}$ of washing water and SRC produced 
Pada perlakuan tanpa pencucian, $\mathrm{pH}$ yang diukur adalah $\mathrm{pH}$ air perebusan yang mencapai 12,9. Gambar 2 memperlihatkan bahwa sampai pencucian ke-2 terlihat penurunan $\mathrm{pH}$ air pencucian rumput laut yang tidak signifikan. Hal tersebut dikarenakan masih tingginya residu $\mathrm{KOH}$ pada air pencucian yang berasal dari rumput laut. Setelah pencucian ke-3 $\mathrm{pH}$ air baru turun mencapai 10,6. Dan setelah pencucian 4 kali (kontrol) pH turun hingga 9,6.

Setelah rumput laut dipres dan dijemur menjadi SRC kemudian disimpan selama dua minggu, $\mathrm{pH}$ SRC turun signifikan menjadi 9,$5 ; 9,1 ; 9,1$; dan 9,0 masing-masing untuk perlakuan tanpa pencucian, pencucian 1, 2, dan 3 kali; sedangkan pada pencucian 4 kali tanpa pengepresan (kontrol) pHSRC mencapai 8,5. Pencucian rumput laut dengan air selain berfungsi menghilangkan kotoran yang masih menempel pada rumput laut juga menyebabkan terjadinya pengenceran konsentrasi $\mathrm{KOH}$ sehingga menyebabkan turunnya nilai $\mathrm{pH}$. Proses pengepresan diduga mampu menurunkan $\mathrm{pH}$ rumput laut secara efektif, karena pengepresan menyebabkan keluarnya air secara paksa baik yang ada di permukaan maupun dari dalam rumput laut yang kemudian membawa residu $\mathrm{KOH}$ keluar sehingga menyebabkan turunnya $\mathrm{pH}$ rumput laut. Selain itu, selama proses pengeringan diduga terjadi drip yang menyebabkan terbawanya residu $\mathrm{KOH}$ bersama air yang keluar dari rumput laut sehingga terjadi penurunan $\mathrm{pH}$ SRC-nya.

\section{Kadar Air}

Kadar air SRC yang dihasilkan berkisar antara $17,75-20,61 \%$ dengan kecenderungan semakin banyak jumlah pencucian mengakibatkan semakin tingginya kadar air SRC pada tiap-tiap perlakuan.
Perlakuan kontrol (pencucian 4 kali) menghasilkan kadar air yang tidak berbeda nyata dibandingkan perlakuan 3 kali pencucian yang diikuti pengepresan (Gambar 3).

Terlihat pada Gambar 3 bahwa perlakuan sebanyak tiga kali pencucian dan kontrol (4 kali pencucian) menunjukkan kadar air SRC yang lebih tinggi dibandingkan ketiga perlakuan lainnya. Hal ini disebabkan oleh semakin sedikitnya jumlah residu $\mathrm{KOH}$ dan garam-garam terlarut lainnya yang masih tersisa atau menempel pada rumput laut dengan semakin banyaknya pencucian yang dilakukan. Penghitungan kadar air secara gravimetri terhadap SRC dipengaruhi oleh banyaknya pengotor seperti residu $\mathrm{KOH}$ dan garam-garam lainnya yang masih menempel pada SRC. Hal ini mengakibatkan berat jenis SRC yang dihasilkan menjadi lebih tinggi. Dengan semakin banyaknya pengotor pada SRC menyebabkan semakin rendah kadar air yang terhitung karena pengotor tersebut diduga merupakan residu $\mathrm{KOH}$ dan garam-garam yang menempel dengan kandungan air yang jauh lebih rendah dibandingkan SRC. Pada perlakuan pencucian 3 kali terlihat kadar air berbeda tidak signifikan dibandingkan kontrol. Hal ini menunjukkan pengurangan residu $\mathrm{KOH}$ dan pengotor lainnya dengan 3 kali pencucian yang diikuti pengepresan hampir sama efektifnya dengan 4 kali pencucian tanpa diikuti pengepresan.

\section{Kadar Abu}

Hasil pengamatan menunjukkan bahwa kadar abu SRC yang dihasilkan berkisar antara 18,5-16,73\% (Gambar 4). Hasil pada Gambar 4 menunjukkan bahwa semakin banyaknya jumlah pencucian yang dilakukan menyebabkan menurunnya kadar abu SRC yang dihasilkan. Hal ini disebabkan oleh berkurangnya

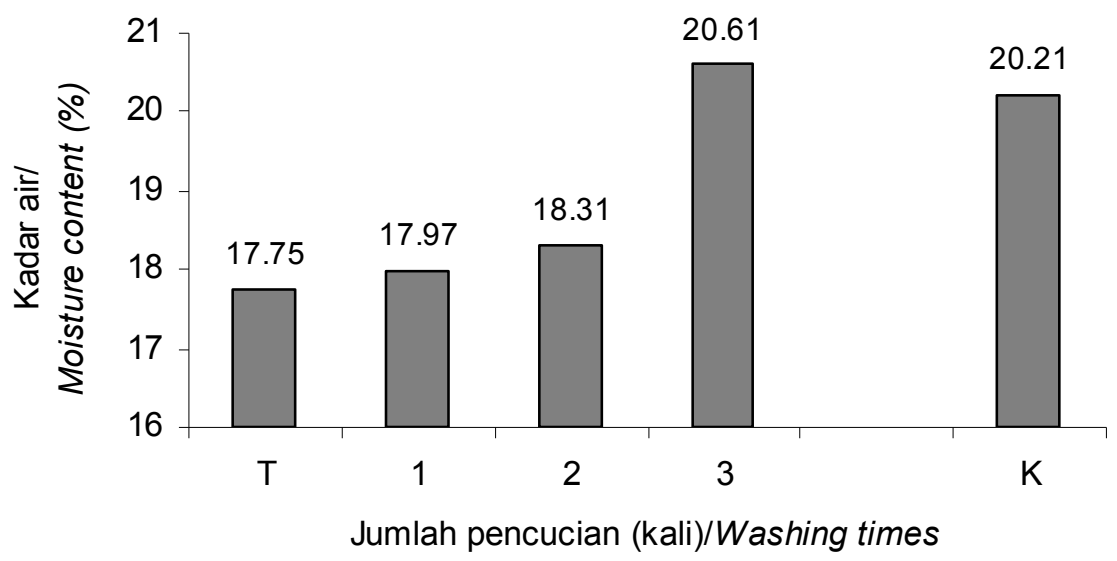

Keterangan/Note: $\mathrm{T}=$ Tidak dicuci/unwashed

$\mathrm{K}=\mathrm{Kontrol} 4$ kali pencucian/ control 4 washing times

Gambar 3. Pengaruh jumlah pencucian terhadap kadar air SRC.

Figure 3. Effect of washing times on moisture content of SRC. 


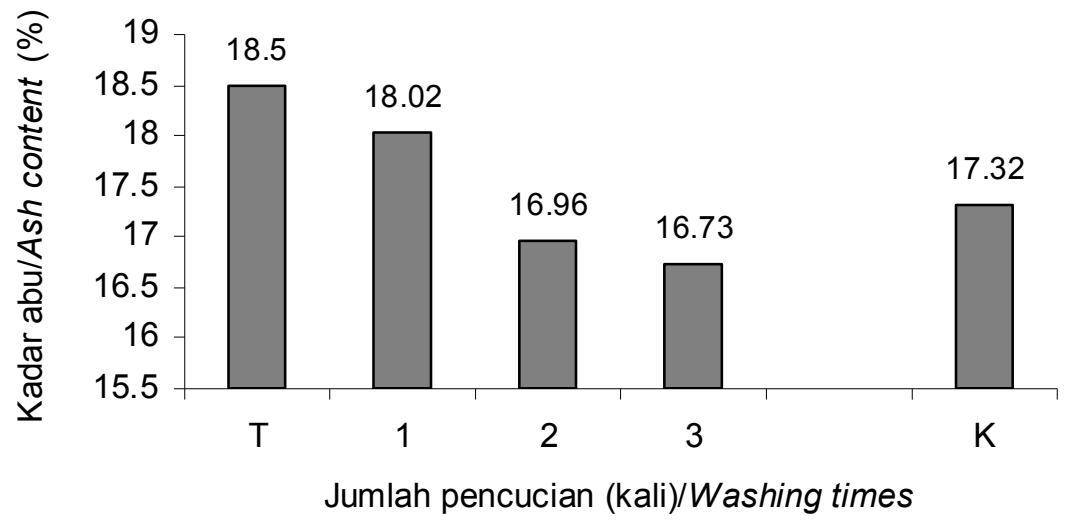

Keterangan/Note: $\mathrm{T}=$ Tidak dicuci/unwashed

$\mathrm{K}=$ Kontrol 4 kali pencucian /control 4 washing times

Gambar 4. Pengaruh jumlah pencucian terhadap kadar abu SRC.

Figure 4. Effect of washing times on ash content of SRC.

garam-garam dan pengotor lainnya yang menempel pada rumput laut melalui pengikatan molekul-molekul pengotor oleh air melalui ikatan hidrogen selama pencucian (Achyadi \& Maulidah, 2004).

Kadar abu yang terdapat pada SRC merupakan mineral-mineral yang secara alami terdapat dalam rumput laut dan juga mineral-mineral terlarut yang masih menempel pada permukaan rumput laut, sehingga jumlah pencucian menyebabkan menurunnya kadar abu SRC yang dihasilkan.

Kadar abu pada perlakuan pencucian sebanyak 2 dan 3 kali memiliki nilai yang lebih rendah dibandingkan kontrol yaitu $17,32 \%$. Hal ini karena adanya proses pengepresan secara mekanis pada SRC perlakuan. Pengepresan mekanis menyebabkan keluarnya air dan residu $\mathrm{KOH}$ beserta pengotor yang terlarut yang menempel di permukaan, dan yang ada di antara sel rumput laut.

Abu dalam bahan pangan adalah sisa bahan organik yang berupa mineral kering dari bahan yang telah dipanaskan hingga $600^{\circ} \mathrm{C}$. Beberapa mineral tidak terbakar meskipun dipanaskan hingga $600^{\circ} \mathrm{C}$ termasuk di antaranya garam-garam $\mathrm{Na}, \mathrm{K}, \mathrm{Ca}$, dan Mg yang dihitung sebagai abu.

\section{Kadar Abu Tak Larut Asam}

Salah satu persyaratan SRC komersial adalah kadar abu tak larut asam (ATA) pada produk yang menunjukkan kontaminasi garam-garam yang secara alami telah ada maupun yang tertinggal selama proses pembuatannya. Kadar abu tak larut asam SRC yang dihasilkan dapat dilihat pada Gambar 5.

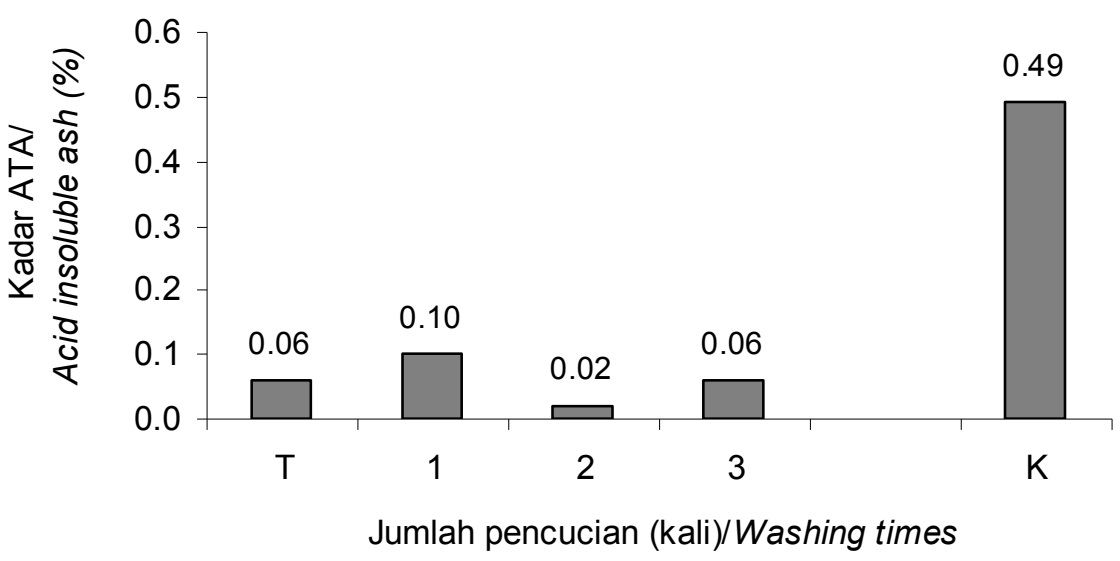

Keterangan/Note: $\mathrm{T}=$ Tidak dicuci/unwashed

$\mathrm{K}=$ kontrol 4 kali pencucian /control 4 washing times

Gambar 5. Pengaruh jumlah pencucian terhadap kadar ATA SRC.

Figure 5. Effect of washing times on acid insoluble ash of SRC. 
Kadar abu tak larut asam pada SRC yang dihasilkan dari masing-masing perlakuan pencucian bervariasi antara 0,02-0,06\%. Secara keseluruhan terlihat bahwa kadar ATA SRC perlakuan berada di bawah SRC kontrol yaitu 0,49\%. Hal ini kemungkinan disebabkan oleh perlakuan pengepresan secara mekanis yang menyebabkan keluarnya garam-garam dan ion-ion yang terlarut dalam $\mathrm{KOH}$ selama perebusan dan bersama dengan keluarnya air dari permukaan dan juga sebagian dari dalam rumput laut secara paksa, sedangkan pencucian tanpa pengepresan pada kontrol hanya mampu menghilangkan kotoran-kotoran yang menempel pada permukaan rumput laut saja sehingga menyebabkan kandunganATA SRC kontrol lebih tinggi dari perlakuan.

Abu tak larut asam adalah garam-garam klorida yang tidak larut dalam asam, yang sebagian besar adalah garam-garam logam berat dan silika. Tingginya kadar abu tak larut asam ini menunjukkan adanya kontaminasi selama proses ekstraksi (Murdinah et al., 1994).

\section{Kadar Sulfat}

Gugus sulfat pada SRC memberikan pengaruh terhadap sifat-sifat kekuatan gel dan kekentalan. Kadar sulfat SRC yang dihasilkan dari masing-masing perlakuan bervariasi antara $15,37-15,50 \%$ sedangkan kadar sulfat kontrol adalah 15,06\% (Gambar 6).

Pada Gambar 6 terlihat adanya keseragaman kadar sulfat dalam SRC yang dihasilkan dan juga SRC kontrol. Hal ini menunjukkan bahwa perlakuan jumlah pencucian maupun proses pengepresan rumput laut setelah perebusan dengan larutan $\mathrm{KOH}$ tidak memberikan pengaruh yang signifikan terhadap kadar sulfat SRC yang dihasilkan. Gugus sulfat pada struktur karaginan berikatan secara kimia membentuk struktur yang kompleks sehingga tidak rusak oleh perlakuan pencucian dan pengepresan fisik.

\section{Kekentalan}

Kekentalan adalah daya aliran molekul dalam sistem larutan. Kekentalan suatu hidrokoloid dipengaruhi oleh beberapa faktor yaitu konsentrasi karaginan, temperatur, jenis karaginan, berat molekul, dan adanya molekul-molekul lain (FAO, 1990). Hasil pengamatan menunjukkan bahwa nilai kekentalan SRC meningkat dengan semakin banyak jumlah pencucian terhadap rumput laut setelah perebusan dalam $\mathrm{KOH}$, yaitu nilai kekentalan terendah pada perlakuan tanpa pencucian sebesar $49 \mathrm{cPs}$ dan tertinggi pada pencucian sebanyak 3 kali sebesar 74 cPs. Namun nilai kekentalan SRC yang dihasilkan sampai dengan 3 kali pencucian masih memiliki kekentalan di bawah SRC kontrol, sebesar $126 \mathrm{cPs}$ (Gambar 7).

Kekentalan larutan karaginan terutama disebabkan oleh sifat karaginan sebagai polielektrolit. Gaya tolakan (repulsion) antar muatan-muatan negatif sepanjang rantai polimer yaitu gugus sulfat, mengakibatkan rantai molekul menegang. Karena sifat hidrofiliknya, polimer tersebut dikelilingi oleh molekulmolekul air yang terimobilisasi, sehingga menyebabkan larutan karaginan bersifat kental (Guiseley et al., 1980).

Semakin banyaknya jumlah pencucian terhadap rumput laut setelah perebusan dalam $\mathrm{KOH}$ menyebabkan hilangnya garam-garam dan pengotor pada rumput dan meningkatkan kemurnian dari karaginan dalam SRC bertambah. Adanya garamgaram yang terlarut dalam karaginan akan menurunkan muatan bersih sepanjang rantai polimer. Penurunan muatan ini menyebabkan penurunan gaya

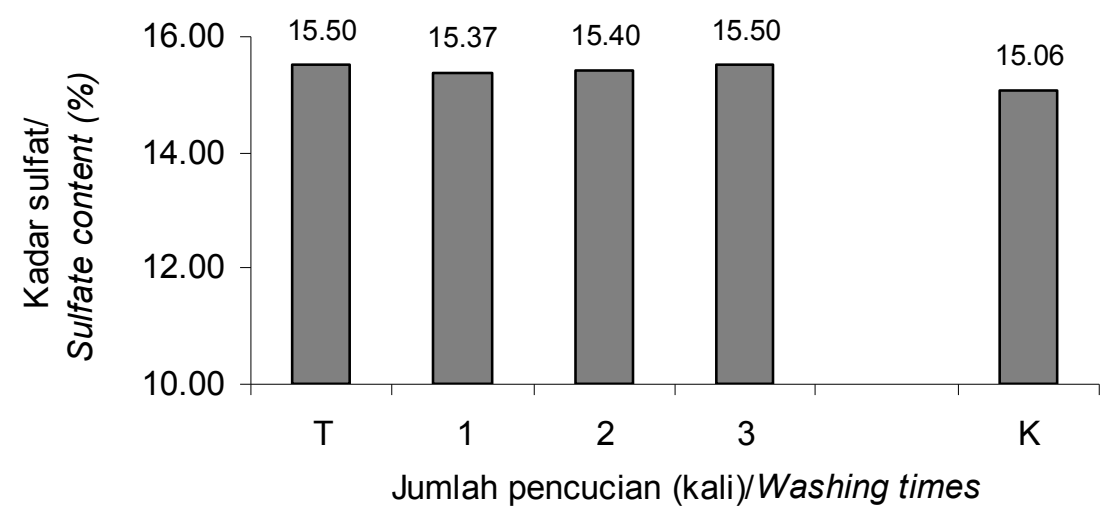

Keterangan/Note: $\mathrm{T}=$ Tidak dicuci/unwashed

$\mathrm{K}=$ Konrol 4 kali pencucian/control 4 washing times

Gambar 6. Pengaruh jumlah pencucian terhadap kadar sulfat SRC.

Figure 6. Effect of washing times on sulfate content of SRC. 


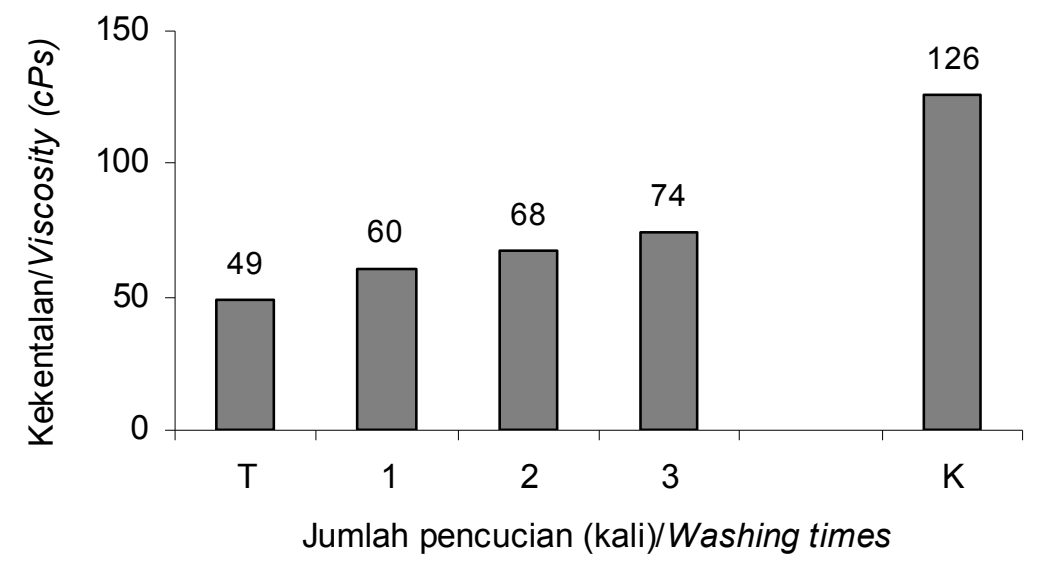

Keterangan/Note: $\mathrm{T}=$ Tidak dicuci/unwashed

$\mathrm{K}=\mathrm{Kontrol} 4 \mathrm{kali}$ pencucian/control 4 washing times

Gambar 7. Pengaruh jumlah pencucian terhadap kekentalan SRC.

Figure 7. Effect of washing times on viscosity of SRC.

tolakan (repulsion) antar gugus-gugus sulfat, sehingga sifat hidrofilik polimer semakin lemah dan kekentalan larutan menurun (Towle 1973). Nilai kekentalan selain dipengaruhi oleh teknik dan jumlah bahan kimia yang diberikan selama proses ekstraksi juga dipengaruhi oleh temperatur, jenis karaginan, berat molekul, dan logam berat yang terkandung di dalam karaginan tersebut (Towle 1973). SRC yang dihasilkan dari semua perlakuan memiliki kekentalan yang lebih rendah dibandingkan kontrol, hal ini diduga karena proses pengepresan menyebabkan keluarnya sebagian karaginan dari rumput laut.

\section{Kekuatan Gel}

Sifat fungsional terpenting dari produk karaginan adalah kemampuan pembentukan gelnya. Berdasarkan pengamatan, nilai kekuatan gel dari masing-masing perlakuan ditunjukkan pada Gambar 8.

Berdasarkan Gambar 8 didapatkan bahwa kekuatan gel terendah terdapat pada perlakuan tanpa pencucian, berbeda nyata dengan perlakuan pencucian, meskipun antara pencucian satu sampai tiga kali serta kontrol tidak berbeda nyata. Hal ini diduga karena kisaran nilai pH SRC yang dihasilkan pada perlakuan pencucian sebanyak 1 sampai 3 kali serta SRC kontrol berkisar antara 8,5-9,1 sedangkan pembentukan gel terbaik adalah pada kisaran $\mathrm{pH} 8$ 9. Pada $\mathrm{pH}$ di atas 9 kestabilan pembentukan gel mulai menurun, demikian juga pada $\mathrm{pH}$ rendah pembentukan gel sulit tercapai. Karaginan dalam larutan memiliki stabilitas maksimum pada $\mathrm{pH} 9$ dan akan terhidrolisis pada $\mathrm{pH}$ di bawah 3,5. Pada $\mathrm{pH} 6$ atau lebih umumnya larutan karaginan dapat

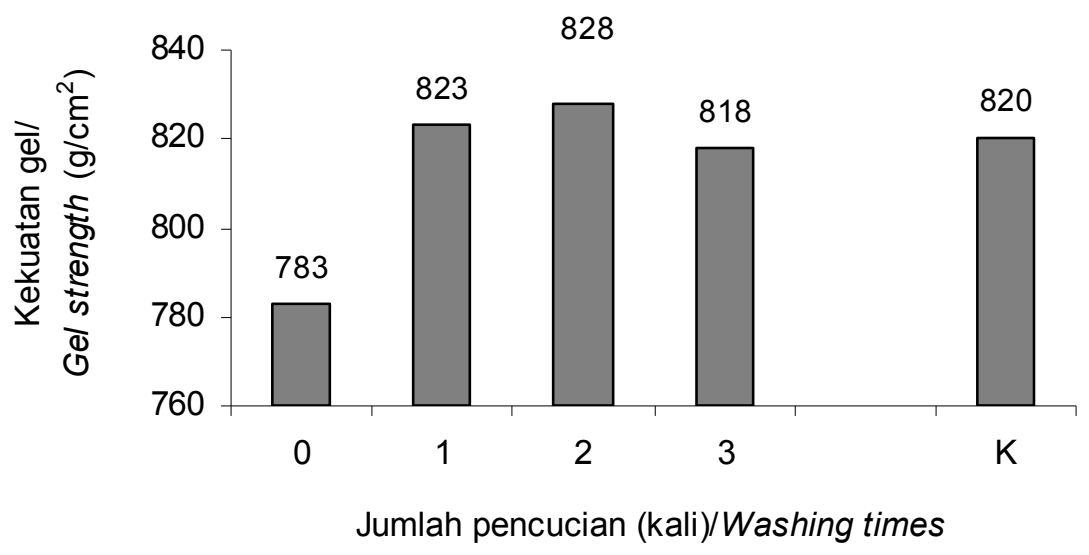

Keterangan/Note: $\mathrm{T}=$ Tidak dicuci/unwashed

$\mathrm{K}=\mathrm{Kontrol} 4 \mathrm{kali}$ pencucian/control 4 washing times

Gambar 8. Pengaruh jumlah pencucian terhadap kekuatan gel SRC.

Figure 8. Effect of washing times on gel strength of SRC. 
mempertahankan stabilitas selama proses produksi (cP Kelco ApS, 2004). Konsistensi gel dipengaruhi beberapa faktor antara lain jenis dan tipe karaginan dan juga adanya ion-ion serta pelarut yang menghambat pembentukan hidrokoloid (Towle 1973).

Kappa karaginan dan iota karaginan akan membentuk gel hanya dengan adanya kation-kation tertentu seperti $\mathrm{K}^{+}, \mathrm{Rb}^{+}$, dan $\mathrm{Cs}^{+}$. Kappa karaginan sensitif terhadap ion kalium dan membentuk gel kuat dengan adanya garam kalium, sedangkan iota karaginan akan membentuk gel yang kuat dan stabil bila ada ion $\mathrm{Ca}^{2+}$, akan tetapi lambda karaginan tidak dapat membentuk gel (Glicksman 1983). Kationkation meningkatkan gelasi dari karaginan melalui stabilisasi pembentukan struktur helik karaginan dengan melindungi muatan gugus sulfat (mengikat gugus heliks dari hidrokoloid kemudian menetralisir gugus sulfat), diikuti dengan koordinasi intermolekuler (ion-dipole) yang berikatan dengan polisakarida membentuk agregat (Braud 1992; Morris \& Chilvers 1983).

\section{Derajat Putih}

Hasil pengamatan terhadap derajat putih menunjukkan bahwa mulai dari perlakuan tanpa pencucian sampai dengan pencucian tiga kali nilai derajat putih SRC yang dihasilkan meningkat dari $55,5 \%$ menjadi $64,3 \%$ sedangkan SRC kontrol memiliki nilai derajat putih sebesar $62,9 \%$ (Gambar 9).

Berdasarkan Gambar 9 terlihat bahwa derajat putih SRC semakin meningkat dengan semakin banyaknya jumlah pencucian, derajat putih tertinggi terdapat pada perlakuan pencucian sebanyak tiga kali yaitu $64,3 \%$ yang melebihi derajat putih SRC kontrol $(62,9 \%)$. Hal ini karena pencucian rumput laut yang telah direbus dalam $\mathrm{KOH}$ mampu menghilangkan kotoran-kotoran dan juga pigmen warna coklat yang terdapat pada larutan $\mathrm{KOH}$ yang masih menempel pada rumput laut. Air sebagai pelarut dapat mengikat molekul-molekul berbagai senyawa dalam bahan pangan melalui ikatan hidrogen (Achyadi \& Maulidah, 2004).

Perlakuan pengepresan rumput laut setelah pencucian mampu mengeluarkan secara paksa residu $\mathrm{KOH}$ dan kandungan airnya, dengan demikian waktu pengeringan SRC dengan sinar matahari juga berkurang. Waktu pengeringan yang lebih pendek akan menyebabkan berkurangnya reaksi pencoklatan selama proses pengeringan terbuka, sehingga derajat putih SRC menjadi lebih tinggi. Hal ini dapat dilihat dari proses pencucian 3 kali yang diikuti proses pengepresan lebih efektif menghilangkan kotoran yang tersisa dibandingkan dengan pencucian sebanyak 4 kali tanpa pengepresan.

Warna SRC merupakan salah satu parameter penting, mengingat SRC digunakan sebagai bahan tambahan pada produk-produk pangan, kosmetika, dan lainnya, sehingga keberadaannya dalam produk diharapkan tidak memberikan pengaruh negatif terhadap kenampakan produk. SRC yang dipasarkan umumnya berwarna agak kekuningan, namun demikian warna yang mendekati putih lebih disukai konsumen.

\section{KESIMPULAN}

Dari percobaan dapat disimpulkan bahwa pencucian rumput laut dua kali diikuti dengan pengepresan menghasilkan SRC yang cukup baik

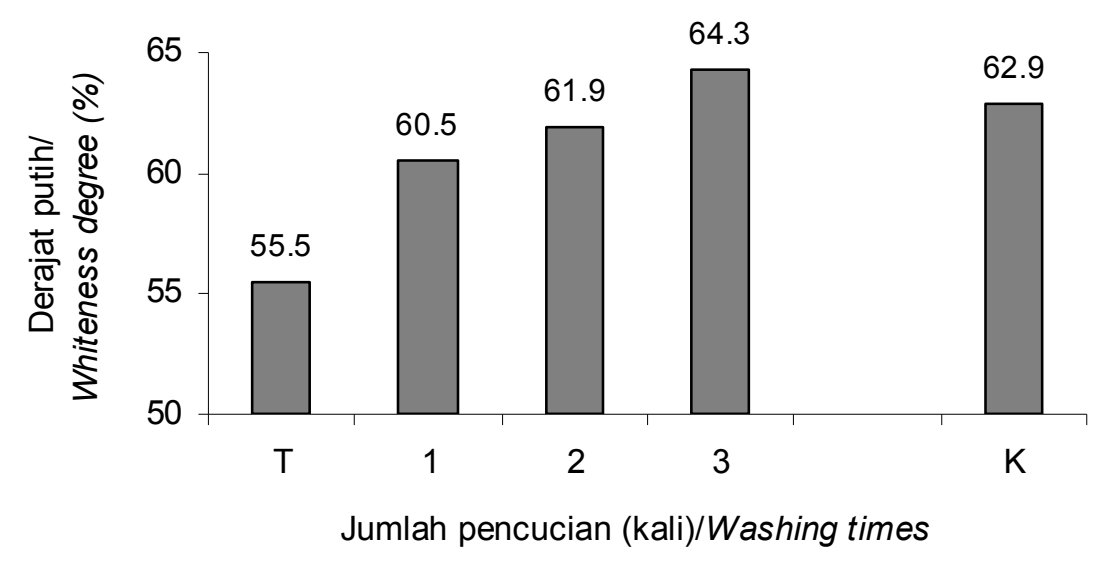

Keterangan/Note: $\mathrm{T}=$ Tidak dicuci/unwashed

$\mathrm{K}=$ Kontrol 4 kali pencucian/control 4 washing times

Gambar 9. Pengaruh jumlah pencucian terhadap derajat putih SRC.

Figure 9. Effect of washing times on whiteness degree of SRC. 
karena kadar abu dan kadar abu tak larut asam dari SRC yang dihasilkan lebih rendah dari kontrol, sedangkan kadar air, kadar sulfat, dan kekuatan gel produk SRC sama dengan yang diolah dengan kontrol, yaitu pencucian empat kali tanpa pengepresan, meskipun kekentalan dan derajat putihnya sedikit lebih rendah. Dapat dikatakan bahwa perlakuan pengepresan secara efektif mengurangi penggunaan air dalam proses pengolahan SRC melalui pengurangan jumlah pencucian.

\section{DAFTAR PUSTAKA}

Achyadi, N.S. dan Maulidah, I. 2004. Pengaruh banyaknya pencuci dan ketebalan masakan pada proses sentrifugal terhadap kualitas gula. Infomatek. (6)4: 193-210.

Bixler, H.J. and Johndro, K.D. 2000. Phillipine natural grade or semi-refined carrageenan. In Phillips, G.O and Williams, P.A. (eds.). Handbook of Hydrocolloids. CRC press. p. 425-442.

Braud, E.E. 1992. Mechanism of galactan gelation. Food Hydrocolloids 6: 25-43.

cP Kelco ApS. 2004. Carrageenan. Denmark. http:// www.cPKelco.com. Diakses tanggal 15 Agustus 2007.

FAO. 1986. Specification for identity and purity of certain food additives. Food and Agriculture Organization. FAO and Nutrition Paper. 34: 22
FAO. 1990. Training manual on gracilaria culture and seaweed processing in China. Food and Agriculture Organization. FAO and Nutrition Paper. Rome. p. 3742.

Glicksman, M. 1983. Food Hydrocolloids. Volume I. CRC Press Boca Raton, Florida. 207 pp.

Guiseley, K.B., Stanley, N.F., and Whitehouse, P.A. 1980. Carrageenan. In Davids, R.L. (ed.). Handbook of Water Soluble Gums and Resins. London, Mc Graw Hill Book Company, New York, Toronto. p. 125-142.

Hellebust J.A. and Cragie JS. 1978. Handbook of Phycological Methods. Cambridge University Press, London. p. 54-66.

Horwitzs, S. 1980. Official Method of Analysis. $13^{\text {rd }}$ (ed). Washington DC. 1018 pp.

Marine Colloid FMC. 1978. Raw Material Test Laboratory Standard Practice. Marine Colloids. Div. Corp. Springfield, New Jersey, USA. 53 pp.

Morris, M.J. and Chilvers, G.R. 1983. Rheological studies of specific cation forms of kappa carrageenan gels. Carbohydrate Polymers. 3: 129-141.

Murdinah, Suryaningrum, Th.D., Indriyati, N., dan Rahayu, U. 1994. Pemisahan karaginan dengan KCL dari filtrat hasil ekstraksi Eucheuma cottonii. J. Penel. Pasca Panen Perikanan. 77: 25-32.

Towle G.A. 1973. Carrageenan. In Whistler, R.L. (ed.). Industrial Gums. Second Edition. Academic Press, New York. p. 83-114. 